\title{
Environmental Improvement Through Forest Products Research
}

Forests and their products are essential to the economic and environmental health of today's society. But sound use of forest products requires attention to global warming, recycling, waste reduction, and other environmental concerns. The 1989 Forest Products Research Conference, held during 3-5 October 1989 at the USDA Forest Service's Forest Products Laboratory (FPL), in Madison, Wisconsin, USA, concentrated on these important subjects.

The Conference theme, 'Improving the Environment through Forest Products Research', attracted more than 100 research workers, wood industry representatives, and marketing specialists. Opening-day speakers discussed the long-term use of the renewable wood resource from the perspectives of the International Association of Fish and Wildlife Agencies, the Congressional Research Service, the Office of Technology Assessment, and university and government research workers. Subsequent presentations focused on forest management and utilization, manufacturing and conversion, and product use, disposal, and recovery. Among the week's speakers was R. Max Peterson, Chief Emeritus of the Forest Service. The Conference concluded with a review of the global trends that will shape future research efforts.

'During the Conference, we've seen how some activities of the forest products community contribute to envi- ronmental problems: but, more importantly, we've seen how research by the forest products community is helping to solve those problems', said Conference Co-chairman Steven Smulski, of the University of Massachusetts. 'I hope people come away sharing my optimism about the progress we are making.'

'The primary thing we want to encourage through this Conference is to expand our thinking as researchers', said John Erickson, Director of the Forest Products Laboratory and Conference Co-chairman. 'We also hope it expands partnerships between the Forest Service, industry, and universities, to improve the utilization of wood.'

The National Planning Committee on Forest Products Research, consisting of Bruce Cutter, University of Missouri; Ali Moslemi, University of Idaho; and Richard Thomas, North Carolina State University, assisted the Conference co-chairmen in setting the agenda and moderating the Conference sessions. Founded in 1910, the Forest Products Laboratory is the Forest Service's centralized wood research facility.

DEBRA SQUIRE
USDA Forest Products Laboratory
One Gifford Drive
Madison
Wisconsin 53705
USA.

DEBRA SQUIRE

Laboratory

Madison

USA.

\section{Environmental Regulation a Fact of Life for Industry}

In May 1989, Edgar Smith Woolard, jr, Chairman of E.I. duPont de Nemours \& Company, addressed the American Chamber of Commerce in London, England, on the subject of industry and the environment. Among other things, he urged industry to accept the reality that environmental regulation world-wide is a fact of life, and consequently, it (industry) must internalize environmental costs and apply the same high environmental performance standards to its operations at home and abroad. Otherwise the public, which endorses the concept of a clean environment, will continue to view industry as the villain. Industry, he concluded, if it is to retain public and market confidence, will have to be seen in a different colour from that in which it has been in the past: 'and that colour had better be green.'

In my work as a consultant to multinational corporations on management and communications policy for international environmental affairs, I find that many companies are ill-equipped to deal successfully with the world-wide environmental policy and management challenges that lie ahead. They are ill-equipped by reason of (i) the absence of strong leadership and commitment from their boards and top officers, (ii) widespread corporate apathy, and (iii) organization and communications structures that do not furnish senior management with adequate resources and information on which sound environmental policy-decisions must be based.

For example, a major producer of chemicals is encountering resistance in middle management to the concept that the company is indeed a global company, let alone that sound environmental management is an integral part of doing business world-wide. Another industrial giant, five years after Bhopal, is just beginning to establish a world-wide auditing programme in its facilities. Still another has a minuscule, albeit growing, environmental staff to cope with its expanding offshore operations.
There can be no doubt that many transnational corporations have moved quickly and decisively to deal with environmental, industrial health, and safety, problems in their headquarters countries and in offshore operations. However, as they wrestle with the usual management questions such as centralized versus decentralized decision-making, priorities, internal communications, staffing, and training, they must also integrate the environmental dimension into the production process in countries with different cultures, traditions, and levels of economic development. This requires information on environmental regulations, standards, and legislation, in the countries concerned, as well as knowledge of local public opinion, local politics, environmental organizations, and other factors that affect company operations.

In addition, human sensitivities and political adroitness are of vital importance in achieving stated policygoals. These elements, however, are often overlooked, and it is only too easy to commit egregious and costly errors that can adversely affect a corporate image and the 'bottom line'. For example, a well-known electronics equipment manufacturer recently donated air pollution monitoring equipment to a developing country, but failed to provide manuals in the native language or training in their use. This failure, in the eyes of the recipient, reflected the superficial nature of the donor's generosity.

Multinational corporations would do well to follow duPont Chairman Woolard's leadership and advice. But they will have to recast their own internal management structures, policies, and staff attitudes, if they are to be environmentally effective in their external relations with the market and the wider public.

\author{
Whitman Bassow, President \\ Whitman Bassow \& Associates, Inc. \\ 655 Third Avenue \\ New York, NY 10017 \\ USA.
}

